\title{
Removal of Arsenic(III) Ion from Aqueous Media Using Complex Nickel-Aluminum and Nickel-Aluminum-Zirconium Hydroxides
}

\author{
Fumihiko Ogata ${ }^{1}\left(\mathbb{D}\right.$, Noriaki Nagai $^{1}$, Megumu Toda $^{2}$, Masashi Otani ${ }^{2}$, \\ Chalermpong Saenjum ${ }^{3,4} \mathbb{D}$, Takehiro Nakamura ${ }^{1}$ and Naohito Kawasaki ${ }^{1,5, * \mathbb{D}}$ \\ 1 Faculty of Pharmacy, Kindai University, 3-4-1 Kowakae, Higashi-Osaka, Osaka 577-8502, Japan; \\ ogata@phar.kindai.ac.jp (F.O.); nagai_n@phar.kindai.ac.jp (N.N.); nakamura@phar.kindai.ac.jp (T.N.) \\ 2 Kansai Catalyst Co. Ltd., 1-3-13, Kashiwagi-cho, Sakai-ku, Sakai, Osaka 590-0837, Japan; \\ megumu.toda@kansyoku.co.jp (M.T.); masashi.ootani@kansyoku.co.jp (M.O.) \\ 3 Faculty of Pharmacy, Chiang Mai University, Suthep Road, Muang District, Chiang Mai 50200, Thailand; \\ chalermpong.saenjum@gmail.com \\ 4 Cluster of Excellence on Biodiversity-based Economics and Society (B.BES-CMU), Chiang Mai University, \\ Suthep Road, Muang District, Chiang Mai 50200, Thailand \\ 5 Antiaging Center, Kindai University, 3-4-1 Kowakae, Higashi-Osaka, Osaka 577-8502, Japan \\ * Correspondence: kawasaki@phar.kindai.ac.jp; Tel.: +81-6-4307-4012
}

Received: 12 May 2020; Accepted: 12 June 2020; Published: 14 June 2020

\begin{abstract}
The technology of wastewater treatment involving removal of heavy metals using complex metal hydroxides is reported. In this study, complex nickel-aluminum (NA11 and NA12) and nickel-aluminum-zirconium (NAZ1 and NAZ2) hydroxides were prepared for the removal of arsenite ions, As(III), from aqueous solution. The characteristics of each adsorbent were evaluated, and the adsorption capacity and adsorption mechanism were determined. The adsorption capacity of As(III) on NAZ1 $\left(15.3 \mathrm{mg} \mathrm{g}^{-1}\right)$ was greater than that on NA11 $\left(9.3 \mathrm{mg} \mathrm{g}^{-1}\right)$. Coverage is directly related to the specific surface area with a correlation coefficient of 0.921 . Ion exchange involving sulfate ions in the interlayer of the adsorbent also plays a role in the mechanism of As(III) adsorption as demonstrated by correlation coefficients of 0.797 and 0.944 for the NA11 and NAZ1, respectively. The results demonstrate the usefulness of NAZ1 in removing As(III) from aqueous media.
\end{abstract}

Keywords: complex nickel-aluminum-zirconium hydroxide; arsenic ion; adsorption

\section{Introduction}

The United Nations has adopted 17 goals as part of its 2030 agenda to develop a sustainable future for all. Issues of clean water and sanitation (Goal No. 6) and undersea water (Goal No. 14) are particularly relevant to the development of an acceptable global water environment [1]. Heavy metals and their compounds are useful in many areas of human endeavor [2]. However, their excessive use leads to an increasing presence in aqueous environments [3]. Arsenic (As) pollution in aquatic systems is a global issue owing to its high toxicity and chronic effects on human health $[4,5]$. Arsenic pollution in drinking water is a major concern in developing countries. Previous studies have identified a relationship between arsenic exposure and diseases such as asthma and hyperglycemia [6,7]. Arsenic and inorganic arsenic compounds are classified as Group 1 human carcinogens by the International Agency for Research on Cancer [8]. The World Health Organization has established $0.01 \mathrm{mg} \mathrm{L}^{-1}$ as the maximum permissible arsenic content in potable water to protect human health [9]. The predominant forms of inorganic arsenic in aquatic systems are $\mathrm{As}(\mathrm{V})$ (arsenate) and $\mathrm{As}(\mathrm{III})$ (arsenite). Arsenic is a ubiquitous element, occurring from natural sources (such as wearing of arsenic bearing minerals and 
volcanic eruptions) and anthropogenic activities (such as mining, glassware production, dyes, drugs, and pesticide industries) [10-12]. As(III) is highly toxic, soluble, and mobile compared to As(V) [13,14]. Therefore, there is a need for simple, efficient, and inexpensive techniques to remove As(III) from aquatic systems.

Adsorption techniques using a variety of materials have been shown to be superior to conventional techniques such as precipitation, reverse osmosis, filtration, and biological treatment for As(III) removal [2,15]. Complex metal hydroxides are useful adsorbents for the removal of heavy metals from aqueous systems [16,17]. A complex metal hydroxide, or layered double hydroxide, contains divalent and trivalent cations at the octahedral positions of brucite-like layers. Anions are incorporated in the interlayer region for charge neutrality [18,19]. Multi-metal hydroxides exhibit substantially different physicochemical characteristics than their single-metal counter parts. Their properties depend on the identities and molar ratios of the constituent metals [20]. Many researchers have reported As(III) removal using adsorbents such as a Mn-oxide-doped Al oxide [15], an iron-zirconium binary oxide [13], a calcined Mg-Fe-La hydrotalcite-like compound [21], a nickel-aluminum hydroxide [16], and an Fe-Mg type hydrotalcite [17].

Incorporation of zirconium $\left(\mathrm{Zr}^{4+}\right)$ into a complex metal hydroxide such as a $\mathrm{Mg}$-Al-layered double hydroxide has recently been examined [22,23]. Incorporation increases the charge in the metal layer and promises to be an attractive means of generating unique physicochemical properties. Positively charged brucite-like sheets have been prepared containing $\mathrm{Zr}^{4+}$, which randomly occupies the octahedral holes in a close-packed configuration of hydroxide ions [22]. Adsorption of phosphate ion from aqueous media using the $\mathrm{Zr}^{4+}$-containing complex metal hydroxide has been reported [22,23]. However, there have been no reports regarding As(III) adsorption from aqueous media. Arsenic as As(V) (arsenate) or As(III) (arsenite) adopts chemical forms similar to those of phosphorus as P(V) (phosphate) or $\mathrm{P}(\mathrm{III})$ (phosphite). We previously reported that nickel-aluminum-zirconium hydroxide is useful in the removal of phosphate ions from an aqueous phase [24]. This paper focuses on the relationship between As(III) adsorption and the complex nickel-aluminum and nickel-aluminum-zirconium hydroxides. The objectives of this work are to determine the physicochemical characteristics of complex nickel-aluminum and nickel-aluminum-zirconium hydroxides as a function of composition, to evaluate their ability to adsorb As(III) from aqueous media, and to investigate the mechanism of As(III) adsorption.

\section{Materials and Methods}

\subsection{Materials and Chemicals}

Nickel-aluminum and nickel-aluminum-zirconium hydroxides of different compositions were obtained from Kansai Catalyst Co., Ltd., Japan. Nickel-to-aluminum molar ratios of 1 and 0.5 are designated as NA11 and NA12, respectively. Nickel:aluminum:zirconium molar ratios of 0.9:1.0:0.09 and 0.9:0.2:0.09 are denoted as NAZ1 and NAZ2, respectively. Sulfate was included as an exchangeable anion in the interlayer of NA and NAZ. These materials were synthesized by the following method. Nickel(II) sulfate hexahydrate, aluminum sulfate octahydrate, and zirconium(IV) sulfate tetrahydrate were mixed with distilled water $(230 \mathrm{~g})$ at heating. The reaction mixture was added to the distilled water (400 g) at pH 9.0 for $800 \mathrm{rpm}$ at $25^{\circ} \mathrm{C}$. The solution $\mathrm{pH}$ was adjusted using a $25 \%$ sodium hydroxide solution. After mixing for $2 \mathrm{~h}$, the suspension was filtered, washed, and dried at $110{ }^{\circ} \mathrm{C}$ for $12 \mathrm{~h}$. Arsenic(III) standard solution (As(III), $\mathrm{As}_{2} \mathrm{O}_{3}$ and $\mathrm{NaOH}$ in water $\mathrm{pH} 5.0$ with $\mathrm{HCl}$ ), hydrochloric acid, and sodium hydroxide were purchased from FUJIFILM Wako Pure Chemical Co., Japan. The purity grade of all reagents was special grade and the quality of water (resistivity) was $18.2 \mathrm{M} \Omega \cdot \mathrm{cm}$ at $25^{\circ} \mathrm{C}$.

\subsection{Physicochemical Properties of Adsorbents}

The NA11, NA12, NAZ1, and NAZ2 adsorbents were characterized as follows. The morphologies and crystallinities of the adsorbents were determined by scanning electron microscopy with an SU1510 
instrument (Hitachi High-technologies Co., Tokyo, Japan) and a Mini Flex II X-ray diffraction analyzer (Rigaku Co., Tokyo, Japan), respectively. The surface area was determined by a specific surface analyzer N42-25E (Quantachrome Instruments Japan G.K., Kanagawa, Japan). Surface hydroxyl groups were assayed using the fluoride-ion adsorption method [25]. Briefly, the adsorbent $(0.125 \mathrm{~g})$ was mixed with a $0.01 \mathrm{~mol} \mathrm{~L}^{-1} \mathrm{NaF}$ solution $(50 \mathrm{~mL})$ at $\mathrm{pH}$ 4.6. The solution $\mathrm{pH}$ was adjusted by $0.2 \mathrm{~mol} \mathrm{~L}^{-1}$ acetic acid solution and $0.2 \mathrm{~mol} \mathrm{~L}^{-1}$ acetate buffer solution. The reaction mixture was shaken for $24 \mathrm{~h}$ at $100 \mathrm{rpm}$ and $25^{\circ} \mathrm{C}$ and filtered through a $0.45-\mu \mathrm{m}$ membrane filter. The concentration of fluoride ion before and after adsorption was measured using absorption spectrophotometry (DR890, HACH, Loveland, CO, USA). The amount of fluoride ion adsorbed was calculated (the ratio of the concentration of fluoride ion and the concentration of hydroxyl group is 1:1). The surface $\mathrm{pH}$ of the adsorbent was measured as follows. A 0.1-g quantity of adsorbent was added to $50 \mathrm{~mL}$ distilled water at $\mathrm{pH} 7.0$. The suspension was shaken for $2 \mathrm{~h}$ at $100 \mathrm{rpm}$ and $25{ }^{\circ} \mathrm{C}$ and filtered through a $0.45-\mu \mathrm{m}$ membrane filter. The solution $\mathrm{pH}$ was measured with a digital pH meter (F-73, Horiba, Ltd., Kyoto, Japan) [26].

\subsection{Adsorption Experiments}

NA11, NA12, NAZ1, and NAZ2 in 0.1-g quantities were mixed with $50 \mathrm{~mL}$ of $100 \mathrm{mg} \mathrm{L}^{-1} \mathrm{As}(\mathrm{III})$ solution to determine the extent of As(III) adsorption. Mixtures were shaken for $24 \mathrm{~h}$ at $100 \mathrm{rpm}$ and filtered through a $0.45-\mu \mathrm{m}$ membrane filter. The As(III) concentration of the filtrate was measured by inductively coupled plasma optical emission spectrometry using an iCAP 7600 Duo instrument (ICP-OES, Thermo Fisher Scientific Inc., Kanagawa, Japan). The quantity of As(III) adsorbed was calculated from the difference in As(III) concentration before and after adsorption. To examine the effect of contact time, 0.1 -g quantities of NA11 and NAZ1 were mixed with $50 \mathrm{~mL}$ of a $100 \mathrm{mg} \mathrm{L}^{-1}$ As(III) solution and shaken for $0.5,1,3,6,9,12,16,20$, and $24 \mathrm{~h}$ at $100 \mathrm{rpm}$ and $25^{\circ} \mathrm{C}$. The effect of $\mathrm{pH}$ was studied by mixing the same adsorbents with $50 \mathrm{~mL}$ of $100 \mathrm{mg} \mathrm{L}^{-1} \mathrm{As}(\mathrm{III})$ and adjusting the solution $\mathrm{pH}$ from 2 to 10 using hydrochloric acid or sodium hydroxide. The same adsorbents were mixed with $50 \mathrm{~mL}$ of $1,10,30,50,70$, and $100 \mathrm{mg} \mathrm{L}^{-1} \mathrm{As}(\mathrm{III})$ solutions to study the effect of concentration. These solutions also were shaken for $24 \mathrm{~h}$ at $100 \mathrm{rpm}$ and $25^{\circ} \mathrm{C}$. The quantity of sulfate ion released from adsorbent was measured to elucidate the adsorption mechanism of As(III).

Sulfate ion concentration was determined by ion chromatography using a DIONEX ICS-900 instrument (Thermo Fisher Scientific Inc., Tokyo, Japan), an IonPac AS12A system $(4 \times 200 \mathrm{~mm}$, Thermo Fisher Scientific Inc., Tokyo, Japan), and an AMMS 300 (4 mm, Thermo Fisher Scientific Inc., Tokyo, Japan) micro-membrane filter suppressor. The regenerant and mobile phase were $12.5 \mathrm{mmol} \mathrm{L}^{-1}$ $\mathrm{H}_{2} \mathrm{SO}_{4}$, and $2.7 \mathrm{mmol} \mathrm{L}^{-1} \mathrm{Na}_{2} \mathrm{CO}_{3}+0.3 \mathrm{mmol} \mathrm{L}^{-1} \mathrm{NaHCO}_{3}$, respectively. The flow rate and sample volume were $1.0 \mathrm{~mL} \mathrm{~min}^{-1}$ and $10 \mu \mathrm{L}$ under ambient conditions. The quantity of sulfate ions released from adsorbent were calculated using the levels before and after adsorption in Equation (1):

$$
q=\left(C_{\mathrm{e}}-C_{0}\right) V / W
$$

where $q$ is the quantity of sulfate ion released $\left(\mathrm{mg} \mathrm{g}^{-1}\right) ; C_{0}$ is the concentration before adsorption $\left(\mathrm{mg} \mathrm{L}^{-1}\right) ; C_{\mathrm{e}}$ is the concentration after adsorption $\left(\mathrm{mg} \mathrm{L}^{-1}\right) ; V$ is the solvent volume $(\mathrm{L})$; and $W$ is the weight of the adsorbent $(\mathrm{g})$. Data are presented as the mean \pm standard deviation from 2-3 experiments.

\section{Results and Discussion}

\subsection{Physicochemical Properties of Adsorbents}

The SEM images of each adsorbent are shown in Figure 1. The adsorbents are not perfectly spherical in shape, but no significant differences are observed in the appearance of the adsorbents in this study. 


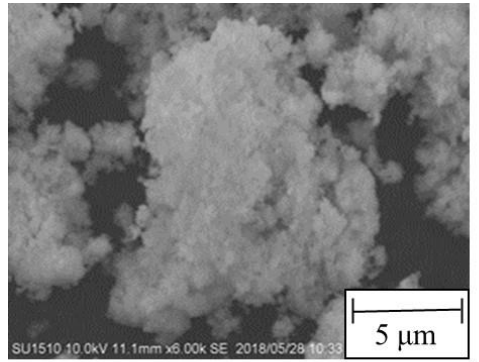

NA1 1

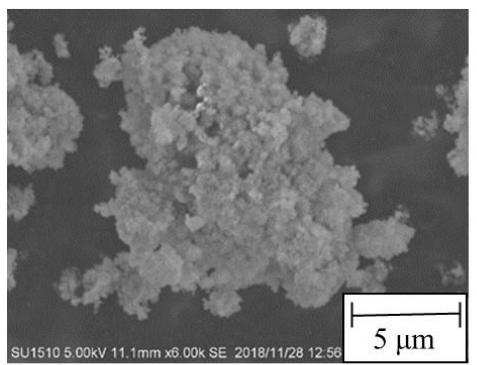

NAZ1

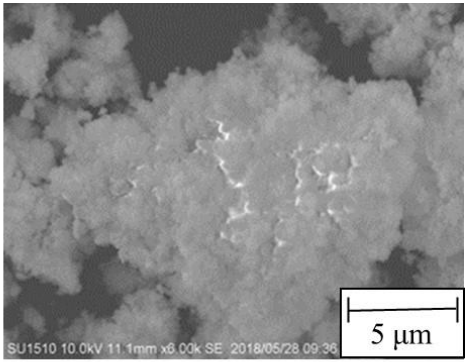

NA12

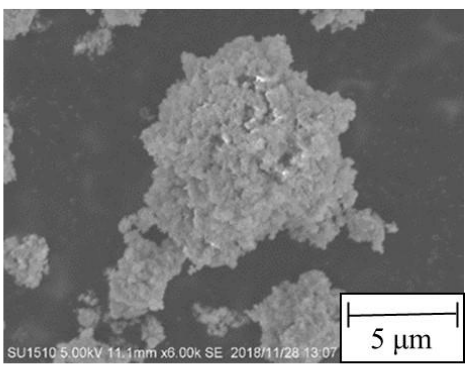

NAZ2

Figure 1. SEM images of adsorbents.

Figure 2 contains the X-ray diffraction patterns. Peaks at (003), (006), (015), and (113) are observed for all adsorbents indicating that they can be indexed to the crystal structure of the complex metal hydroxide. Peaks (003) and (006) are attributed to basal reflections that correspond to the stacking of the brucite-like sheets [27]. Some NAZ peaks are comparable to those in NA, which indicates that $\mathrm{Zr}^{4+}$ has been successfully incorporated into the octahedral layer of the complex nickel-aluminum hydroxide. Zirconium(IV) insertion alters the distances between metals and between the octahedral layers. Similar trends have been reported in previous investigations [22,23].

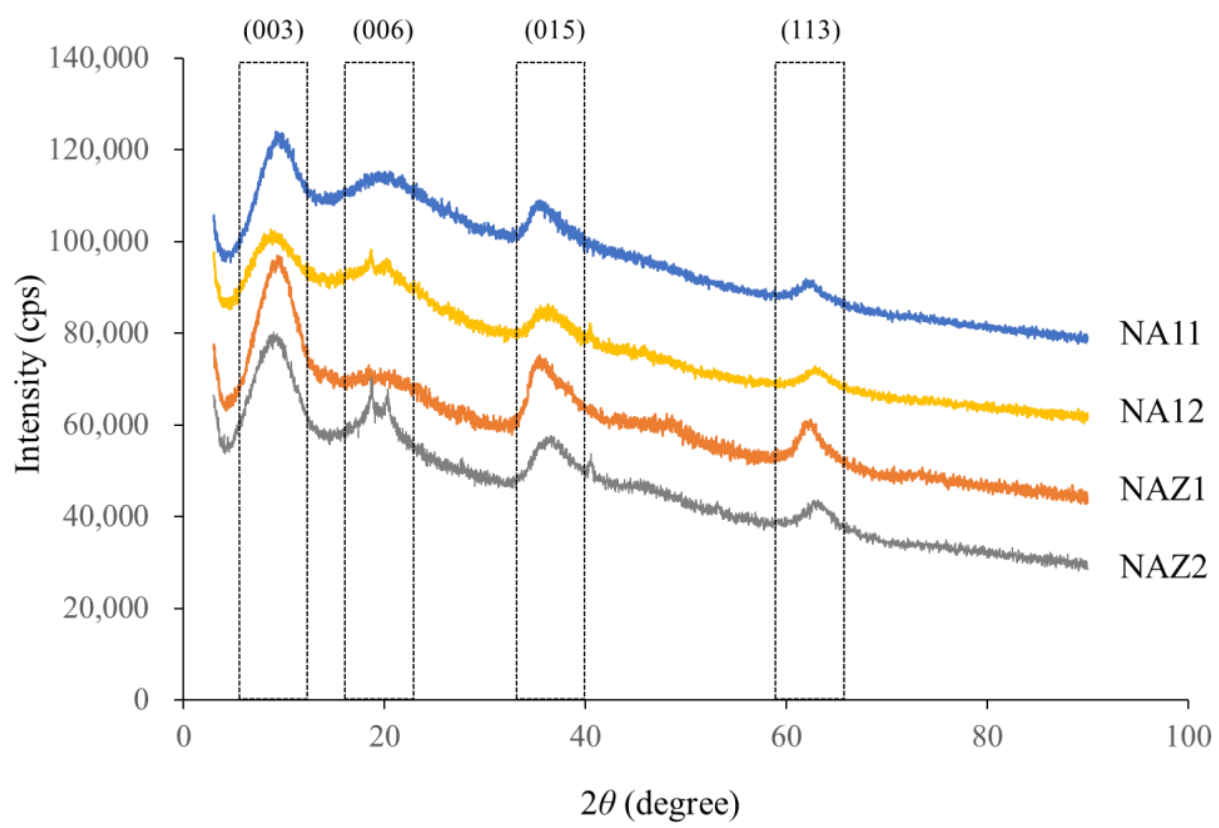

Figure 2. XRD patterns of adsorbents.

Some characteristics of the adsorbents are shown in Table 1. Surface $\mathrm{pH}$ and the number of hydroxyl groups of NA are higher than those of NAZ. However, the specific surface area of NAZ is greater than that of NA. The specific surface area of NAZ1 $\left(51.9 \mathrm{~m}^{2} \mathrm{~g}^{-1}\right)$ is greater than that of 
previously reported $\left(\mathrm{Mg}(\mathrm{AlZr})-\mathrm{LDHs}\left(\mathrm{CO}_{3}\right.\right.$ or $\left.\mathrm{Cl}\right)=2.2-39 \mathrm{~m}^{2} \mathrm{~g}^{-1}$ and $\left.\mathrm{Zr}-\mathrm{MgAl}=49 \mathrm{~m}^{2} \mathrm{~g}^{-1}\right)$ adsorbents, but not of $\left(\mathrm{Zr}-\mathrm{MgAl}-\mathrm{HT}=154 \mathrm{~m}^{2} \mathrm{~g}^{-1}\right)[17,18]$. These results indicate that incorporation of $\mathrm{Zr}^{4+}$ into the octahedral layer of the complex nickel-aluminum hydroxide results in an increase of the specific surface area.

Table 1. Characteristics of adsorbents.

\begin{tabular}{cccc}
\hline Adsorbents & Surface $\mathbf{p H}$ & $\begin{array}{c}\text { Number of Hydroxyl Groups } \\
\left(\mathbf{m} \mathbf{m o l} \mathbf{~ g}^{\mathbf{- 1}}\right)\end{array}$ & $\begin{array}{c}\text { Specific Surface Area } \\
\left(\mathbf{m}^{\mathbf{2}} \mathbf{g}^{\mathbf{- 1}}\right)\end{array}$ \\
\hline NA11 & 7.98 & 1.92 & 22.8 \\
NA12 & 7.63 & 1.62 & 26.4 \\
NAZ1 & 6.18 & 1.08 & 51.9 \\
NAZ2 & 6.21 & 1.51 & 27.8 \\
\hline
\end{tabular}

\subsection{Adsorption Capability of As(III)}

The quantities of As(III) adsorbed onto each adsorbent are shown in Figure 3. The amount adsorbed increases as NA11 < NA12 < NAZ2 < NAZ1, which indicates that NAZ1 should be the most useful for removal of As(III) from aqueous media. Relationships between the quantity of As(III) adsorbed and the three parameters in Table 1 were statistically assessed. The correlation coefficients between the amount adsorbed and the surface $\mathrm{pH}$, amount of hydroxyl groups, and specific surface area were negative 0.570 , negative 0.738 , and positive 0.921 , respectively. Therefore, specific surface area most strongly influences As(III) adsorption capability in solution. The surface properties of adsorbents are very important in the interactions with $\mathrm{As}(\mathrm{III})$ in the aqueous phase. Additionally, the effect of zirconium incorporation on the characteristic of adsorbent and adsorption capability of As(III) was evaluated in detail. Thus, NA11 and NAZ1 were selected to evaluate As(III) adsorption in the following experiments.

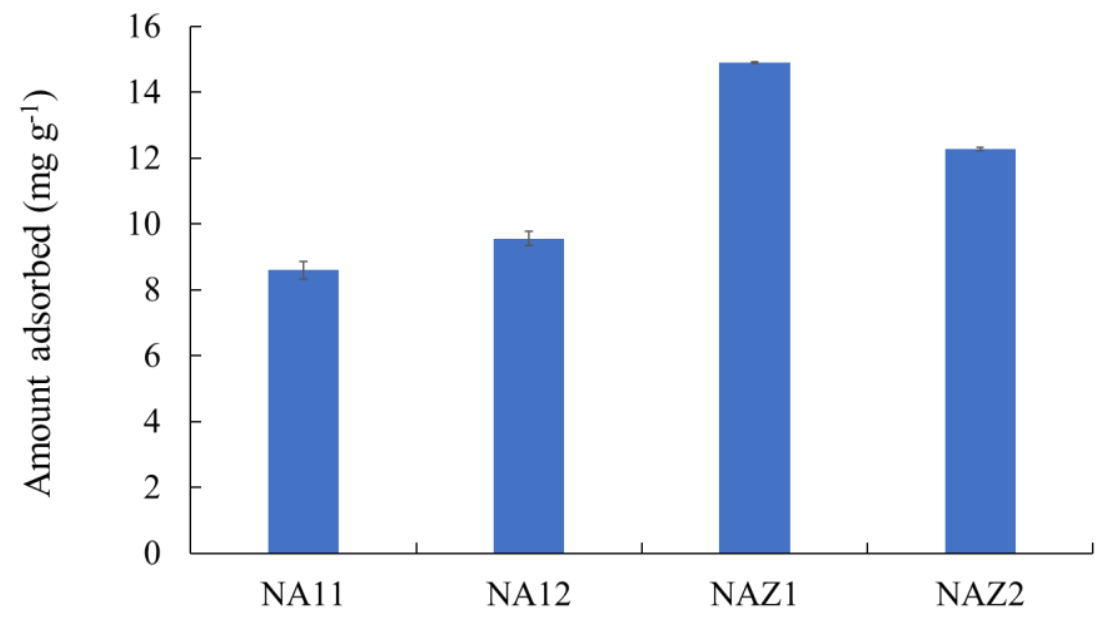

Figure 3. Amount of As(III) adsorbed. Initial concentration: $100 \mathrm{mg} \mathrm{L}^{-1}$, solvent volume: $50 \mathrm{~mL}$, adsorbent: $0.1 \mathrm{~g}$, contact time: $24 \mathrm{~h}$, temperature: $25^{\circ} \mathrm{C}$, agitation speed: $100 \mathrm{rpm}$.

\subsection{Adsorption Kinetics}

The kinetics of As(III) adsorption onto NA11 and NAZ1 were conducted at an initial concentration of $100 \mathrm{mg} \mathrm{L}^{-1}$. Adsorption equilibrium was reached within $24 \mathrm{~h}$ under the experimental conditions (Figure 4). It is clear that adsorption of As(III) onto NA11 and NAZ1 is complicated, because the time to reach equilibrium would be short if the process were controlled by a single factor [21]. Thus, 
the adsorption mechanism was investigated by comparing results to both pseudo-first-order (2) and pseudo-second-order models (3) [28,29]:

$$
\begin{gathered}
\ln \left(q_{e}-q_{t}\right)=\ln q_{e}-k_{1} t \\
\frac{t}{q_{t}}=\frac{t}{q_{e}}+\frac{1}{k_{2} \times q_{e}^{2^{\prime}}}
\end{gathered}
$$

where $q_{e}$ and $q_{t}$ are the amounts of $\mathrm{As}(\mathrm{III})$ adsorbed $\left(\mathrm{mg} \mathrm{g}^{-1}\right)$ at equilibrium and given time $t$, and $k_{1}$ and $k_{2}$ are the pseudo-first-order $\left(\mathrm{h}^{-1}\right)$ and pseudo-second-order $\left(\mathrm{g} \mathrm{mg}^{-1} \mathrm{~h}^{-1}\right)$ rate constants. Table 2 shows the results of fitting the experimental data to the pseudo-first-order (coefficient of determination $=0.817-0.961$ ) and pseudo-second-order (coefficient of determination $=0.978-0.992$ ) models. The adsorption of As(III) onto NA11 and NAZ1 appears to occur by a process of chemisorption. The value of $k_{2}$ with NAZ1 is less than that with NA11, which indicates that As(III) adsorption is favored at NAZ1. This conclusion is supported by the result in Figure 3, which shows that a greater amount of As(III) is adsorbed by NAZ1. Adsorption equilibrium also tends to be established more rapidly using NA11 than NAZ1. Similar trends have been reported in previous studies [13,30]. Additionally, a previous study pointed out the fact that more caution should be exercised in the analysis of kinetic data [31]. Thus, the chi-square analysis $\left(\chi^{2}\right)$ was conducted for the evaluation of kinetic models to avoid including errors. The low value of $\chi^{2}$ indicates that the kinetic model fits to the experimental data [32]. The value of $\chi^{2}$ in the pseudo-first-order model was higher than that in the pseudo-second-order model (Table 2), which indicates that the pseudo-second-order model is considered to be better for the obtained data in this study.

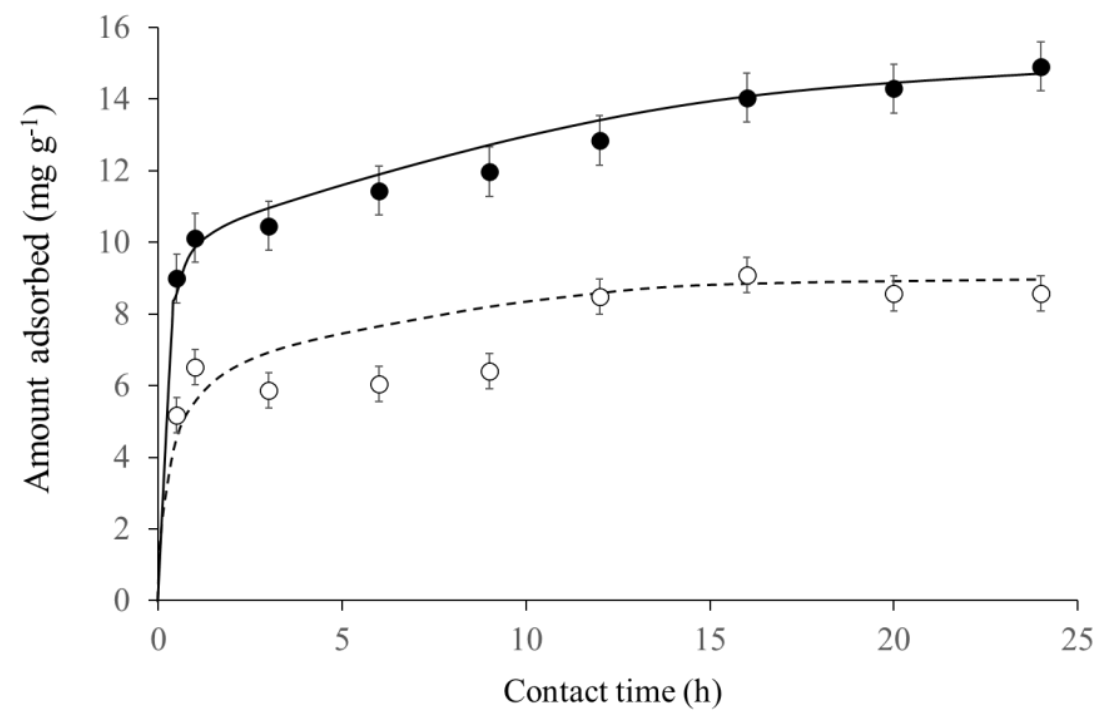

Figure 4. Effect of contact time on the adsorption of As(III) using NA11 and NAZ1. Initial concentration $100 \mathrm{mg} \mathrm{L}^{-1}$, solvent volume $50 \mathrm{~mL}$, adsorbent $0.1 \mathrm{~g}$, contact time $0.5,1,3,6,9,12,16,20$, and $24 \mathrm{~h}$, temperature $25^{\circ} \mathrm{C}$, agitation speed $100 \mathrm{rpm}, \bullet$ : NAZ1, $\bigcirc: \mathrm{NA11}$.

\begin{tabular}{|c|c|c|c|c|c|c|c|c|c|}
\hline \multirow[b]{2}{*}{ Adsorbents } & \multirow[b]{2}{*}{$q_{e}$} & \multicolumn{4}{|c|}{ Pseudo-First-Order Model } & \multicolumn{4}{|c|}{ Pseudo-Second-Order Model } \\
\hline & & $\begin{array}{c}k_{1} \\
\left(\mathrm{~h}^{-1}\right)\end{array}$ & $\begin{array}{c}q_{e} \\
\left(\mathrm{mg} \mathrm{g}^{-1}\right)\end{array}$ & $r^{2}$ & $\chi^{2}$ & $\begin{array}{c}k_{2} \\
\left(\mathrm{~g} \mathrm{mg}^{-1} \mathrm{~h}^{-1}\right) \\
\end{array}$ & $\begin{array}{c}q_{e} \\
\left(\mathrm{mg} \mathrm{g}^{-1}\right)\end{array}$ & $r^{2}$ & $x^{2}$ \\
\hline NA11 & 8.6 & 0.093 & 3.9 & 0.817 & $1.8 \times 10^{2}$ & 0.110 & 9.1 & 0.978 & 1.8 \\
\hline NAZ1 & 14.9 & 6.4 & 6.4 & 0.961 & $2.9 \times 10$ & 0.066 & 15.2 & 0.992 & 1.4 \\
\hline
\end{tabular}

Table 2. Kinetic parameters for the adsorption of $\mathrm{As}(\mathrm{III})$. 


\subsection{Effect of $\mathrm{pH}$ on the Adsorption of As(III)}

Solution $\mathrm{pH}$ is a critical factor in the removal of As(III) from aqueous solution. Figure 5 shows the effect of $\mathrm{pH}$ on As(III) adsorption using NA11 and NAZ1. The quantity of As(III) adsorbed tends to increase with increasing $\mathrm{pH}$. A similar trend using zirconium oxide-ethanolamine has been reported in a previous study [12]. Here, solution $\mathrm{pH}$ tends to increase or decrease slightly after adsorption indicating that the surface of NA11 and NAZ1 may be useful as a neutralizing agent in the wastewater treatment of highly acidic or basic As(III) samples [12,33]. The $\mathrm{pK}_{a, 1}$ of $\mathrm{H}_{3} \mathrm{AsO}_{3}$ is 9.2, which indicates that $\mathrm{As}(\mathrm{III})$ is a neutral species at $\mathrm{pH}$ 9.2. At $\mathrm{pH}>9.2$, anionic forms of $\mathrm{As}(\mathrm{III})$ are produced that undergo ion exchange with sulfate ion from NA11 and NAZ11 under the experimental conditions (see Section 3.5).
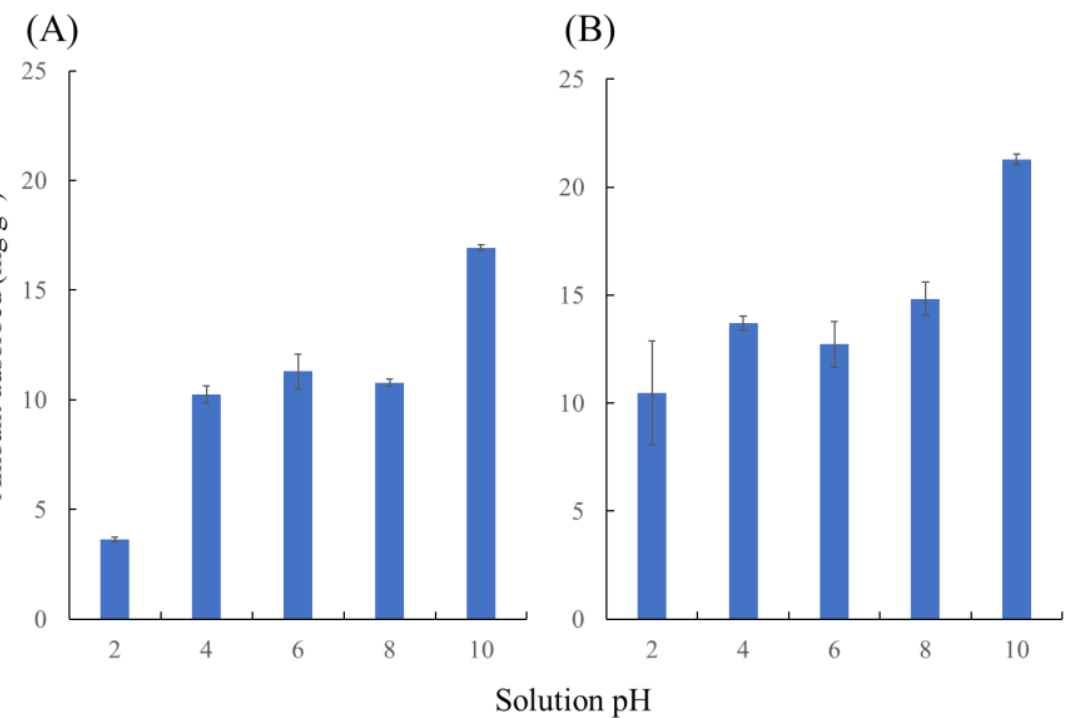

Figure 5. Effect of $\mathrm{pH}$ on the adsorption of As(III) using NA11(A) and NAZ1(B). Initial concentration

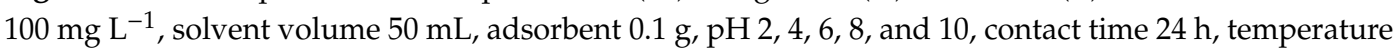
$25^{\circ} \mathrm{C}$, agitation speed $100 \mathrm{rpm}$.

\subsection{As(III) Adsorption Isotherms}

Figure 6 displays adsorption isotherms of As(III) at different temperatures. The data provide considerable insight to the adsorptive behavior of NA11 and NAZ1 towards As(III) in aqueous solution. The quantities of As(III) adsorbed increase with increasing temperatures $\left(10<25<45^{\circ} \mathrm{C}\right)$, which indicates that chemisorption is involved in the adsorption of As(III) on NA11 and NAZ1. The solution $\mathrm{pH}$ was 5.5-6.4 and 5.9-6.2 for NA11 and NAZ1 in all experimental temperatures. Thus, the predominant form of As(III) was not affected by the temperature under our experimental conditions.

Langmuir and Freundlich models were applied to provide a more quantitative description of the relationship between the quantity of $\mathrm{As}(\mathrm{III})$ adsorbed and the solute concentration. The Langmuir model is described by Equation (4) [34]:

$$
1 / q=1 /\left(W_{s} a C_{e}\right)+1 / W_{s}
$$

where $q$ is the quantity of $\mathrm{As}(\mathrm{III})$ adsorbed $\left(\mathrm{mg} \mathrm{g}^{-1}\right), W_{\mathrm{s}}$ is the maximum amount of As(III) adsorbed $\left(\mathrm{mg} \mathrm{g}^{-1}\right), a$ is the Langmuir isotherm constant (binding energy) $\left(\mathrm{L} \mathrm{mg}^{-1}\right)$, and $C_{e}$ is the equilibrium concentration $\left(\mathrm{mg} \mathrm{L}^{-1}\right)$. The Langmuir isotherm is applicable to monolayer coverage by the adsorbate. The Freundlich model is described by Equation (5) [35]:

$$
\log q=\frac{1}{n} \log C+\log k,
$$


where $k$ and $1 / n$ are the adsorption capacity and strength of adsorption, respectively. The Freundlich model describes systems where the surface of the adsorbent is heterogeneous and has sites of different energy [13]. Table 3 shows that the Freundlich model $(\geq 0.970)$ provides better correlation than the Langmuir model $(\geq 0.965)$ except for NAZ1 at $25^{\circ} \mathrm{C}$. Previous studies have reported similar behavior using Fe-based backwashing sludge and polymer adsorbents [33,36]. The maximum adsorption capacity $\left(W_{S}\right)$ of $\mathrm{As}(\mathrm{III})$ increases from $10{ }^{\circ} \mathrm{C}$ to $45^{\circ} \mathrm{C}$. It is worth noting that in the experimental conditions used, equilibrium data (Figure 6) suggest that the plateau for maximum adsorption was not reached. The maximum adsorbed amounts calculated in the Langmuir fitting, however, are lower than some values measured experimentally, which may be due to the use of a linearized equation (Equation (4)) to mathematically model the results. This indicates that the adsorption of As(III) on NA11 and NAZ1 is an endothermic process, which was supported by the results in Figure 6. In the Freundlich model, $n$ is the heterogeneity factor. Therefore, when $1 / n=0.1-0.5$, adsorption occurs easily, and when $1 / n>2$, adsorption is difficult [37]. The values of $1 / n=0.13-0.97$ obtained in this study indicate that As(III) adsorption onto NA11 and NAZ1 is favored in aqueous solution.

(A)

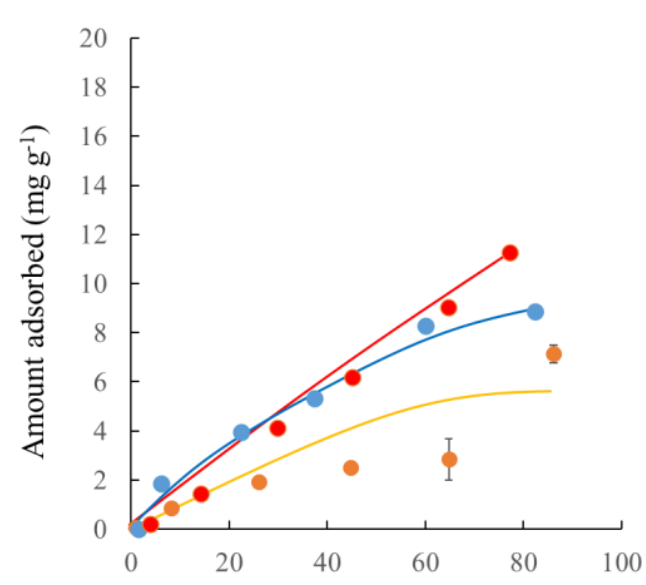

(B)

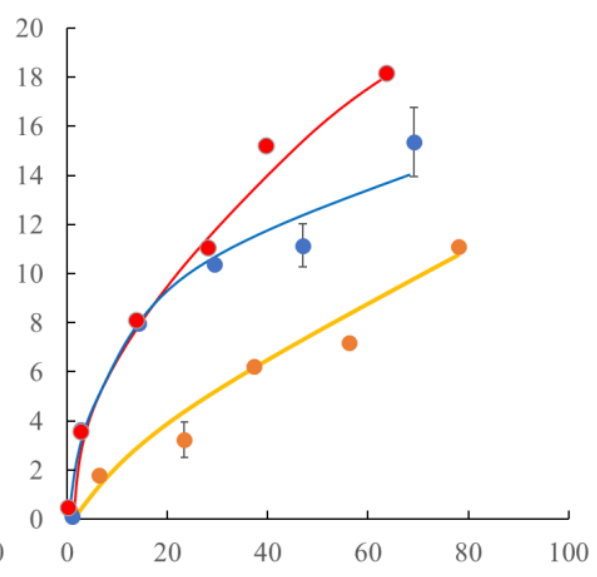

Equilibrium concentration $\left(\mathrm{mg} \mathrm{L}^{-1}\right)$

Figure 6. Effect of temperature on the adsorption of As(III) using NA11 (A) and NAZ1 (B). Initial concentration $1,10,30,50,70$, and100 $\mathrm{mg} \mathrm{L}^{-1}$, solvent volume $50 \mathrm{~mL}$, adsorbent $0.1 \mathrm{~g}$, contact time $24 \mathrm{~h}$, $\mathrm{pH}$ 5.5-6.4 and 5.9-6.2 for NA11 and NAZ1, temperature $10(\bullet), 25(\bullet)$, and $45^{\circ} \mathrm{C}(\bullet)$, agitation speed $100 \mathrm{rpm}$.

Table 3. Langmuir and Freundlich constants for the adsorption of As(III).

\begin{tabular}{cccccccc}
\hline \multirow{2}{*}{ Adsorbents } & $\begin{array}{c}\text { Temperature } \\
\left({ }^{\circ} \mathbf{C}\right)\end{array}$ & \multicolumn{3}{c}{ Langmuir Constants } & \multicolumn{2}{c}{ Freundlich Constants } \\
\cline { 3 - 8 } & 10 & $\begin{array}{c}\boldsymbol{W}_{\boldsymbol{s}} \\
\left(\mathbf{m g ~ g}^{\mathbf{- 1}}\right)\end{array}$ & $\begin{array}{c}\boldsymbol{a} \\
\left(\mathbf{L ~ m ~} \mathbf{~ m}^{-\mathbf{1}}\right)\end{array}$ & $\boldsymbol{r}^{\mathbf{2}}$ & $\mathbf{l o g} \boldsymbol{k}$ & $\mathbf{1 / n}$ & $\boldsymbol{r}^{\mathbf{2}}$ \\
\hline \multirow{3}{*}{ NA11 } & 6.1 & 0.02 & 0.965 & -0.1 & 0.91 & 0.970 \\
& 25 & 9.3 & 0.04 & 0.982 & -0.1 & 0.56 & 0.991 \\
& 45 & 15.4 & 0.006 & 0.989 & -1.4 & 0.13 & 0.996 \\
\hline \multirow{3}{*}{ NAZ1 } & 10 & 6.3 & 0.09 & 0.996 & -0.3 & 0.70 & 0.989 \\
& 25 & 15.3 & 0.01 & 0.935 & -0.4 & 0.97 & 0.768 \\
& 45 & 16.6 & 0.10 & 0.977 & 0.29 & 0.54 & 0.999 \\
\hline
\end{tabular}

In this study, sulfate ions are present in the interlayer of the NA11 and NAZ1 absorbents. Figure 7 shows the relationship between the amount of As(III) adsorbed and the amount of sulfate ion released from NA11 and NAZ1. The correlation coefficients for release from NA11 and NAZ1 are 0.797 and 0.944 , respectively. The results indicate that the release of sulfate from NA11 and NAZ1 by ion exchange has a role in the adsorption mechanism of As(III). 
(A)

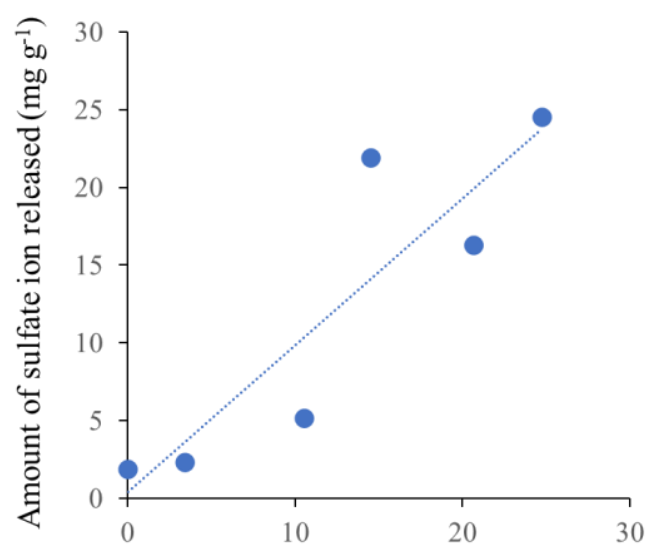

(B)

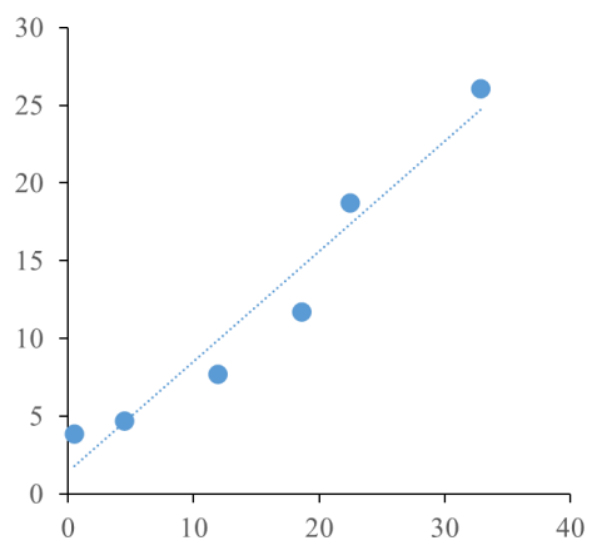

Amount of As(III) adsorbed ( $\left.\mathrm{mg} \mathrm{g}^{-1}\right)$

Figure 7. Relationship between amount of As(III) adsorbed and amount of sulfate ion released using NA11 (A) and NAZ1 (B). Initial concentration 1, 10, 30, 50, 70, and100 $\mathrm{mg} \mathrm{L}^{-1}$, solvent volume $50 \mathrm{~mL}$, adsorbent $0.1 \mathrm{~g}$, $\mathrm{pH} 10$, contact time $24 \mathrm{~h}$, temperature $25^{\circ} \mathrm{C}$, agitation speed $100 \mathrm{rpm}$.

\subsection{Comparison of Adsorption Capability of As(III)}

Table 4 summarizes comparisons of As(III) adsorption capability of NA11 and NAZ1 with other reported adsorbents [38-41]. The NAZ1 exhibited a good potential to be used for removal of As(III) from aqueous media compared to other reported adsorbents (except for drinking-water treatment residuals (WTRs)). From these comparisons, NAZ1 is expected to be employed in a commercial process in the future for As(III) adsorption.

Table 4. Comparison of As(III) adsorption capacity of NA11 and NAZ1 with other reported adsorbents.

\begin{tabular}{|c|c|c|c|c|c|c|c|}
\hline Adsorbents & $\begin{array}{l}\text { Adsorption } \\
\text { Capability } \\
\text { (mg/g) }\end{array}$ & $\mathrm{pH}$ & $\begin{array}{l}\text { Temp. } \\
\left({ }^{\circ} \mathrm{C}\right)\end{array}$ & $\begin{array}{c}\text { Initial } \\
\text { Concentration } \\
(\mathrm{mg} / \mathrm{L})\end{array}$ & $\begin{array}{c}\text { Contact Time } \\
\text { (h) }\end{array}$ & $\begin{array}{c}\text { Adsorbent } \\
(\mathrm{g} / \mathrm{L})\end{array}$ & Ref. \\
\hline ZrPACM-43 & 0.8 & $<5$ & 50 & 100 & 2 & 13 & [3] \\
\hline Al-HDTMA-sericite & 0.433 & 4.5 & - & 2 & $\begin{array}{c}\text { Approximately } \\
6.7\end{array}$ & 1 & [38] \\
\hline $\begin{array}{c}\text { Iron } \\
\text { hydroxide-coated } \\
\text { alumina }\end{array}$ & 9.0 & 6.6 & $20 \times 0.5$ & $7.5-135$ & 48 & $1-25$ & [39] \\
\hline $\begin{array}{c}\text { Silica gel } \\
\text { impregnated with } \\
\text { ferric hydroxide }\end{array}$ & 4.5 & 7.0 & $20-23$ & 1 & 15 & - & [40] \\
\hline WTRs & 15 & $6.0-6.5$ & 23 & $375-3000$ & 48 & 25-200 & [41] \\
\hline NA11 & 9.3 & $5.5-6.4$ & 25 & 100 & 24 & 2 & This study \\
\hline NAZ1 & 15.3 & $5.9-6.2$ & 25 & 100 & 24 & 2 & This study \\
\hline
\end{tabular}

\section{Conclusions}

The complex metal hydroxides NA11 and NAZ1 were prepared to study As(III) removal from aqueous media. The specific surface area of NAZ1 $\left(51.9 \mathrm{~m}^{2} \mathrm{~g}^{-1}\right)$ was greater than that of NA11 $\left(22.8 \mathrm{~m}^{2} \mathrm{~g}^{-1}\right)$. The quantity of As(III) adsorbed onto NAZ1 (15.3 $\left.\mathrm{mg} \mathrm{g}^{-1}\right)$ was also greater than that adsorbed onto NA11 $\left(9.3 \mathrm{mg} \mathrm{g}^{-1}\right)$. The correlation coefficient between the quantity adsorbed and the specific surface area was 0.921 . The adsorption kinetics followed the pseudo-second-order model (coefficient of determination using NA11 and NAZ1 was 0.978 and 0.992, respectively). Adsorption isotherms data established that As(III) adsorption was an endothermic process. Ion exchange with sulfate ions in the interlayer of the adsorbent was also involved in the As(III) adsorption mechanism. 
Author Contributions: Conceptualization, N.K. and F.O.; investigation, N.N., C.S., and T.N.; resources, M.T. and M.O.; writing—original draft preparation, F.O.; writing-review and editing, F.O. and C.S.; project administration, N.K. All authors have read and agreed to the published version of the manuscript.

Funding: This research was funded by The Research Foundation for Pharmaceutical Sciences.

Conflicts of Interest: The authors declare no conflict of interest.

\section{References}

1. Transforming Our World: The 2030 Agenda for Sustainable Development. Available online: https: //sustainabledevelopment.un.org/post2015/transformingourworld (accessed on 8 May 2020).

2. Mohan, D.; Charles, P. Arsenic removal from water/wastewater using adsorbents-a critical review. J. Hazard. Mater. 2007, 142, 1-53. [CrossRef]

3. Mandal, S.; Sahu, M.K.; Patel, R.K. Adsorption studies of arsenic(III) removal from water by zirconium polyacrylamide hybrid material (ZrPACM-34). Water Resour. Ind. 2013, 4, 51-67. [CrossRef]

4. Hughes, M.F. Arsenic toxicity and potential mechanisms of action. Toxicol. Lett. 2002, 133, 1-16. [CrossRef]

5. Mandal, B.K.; Suzuki, K.T. Arsenic round the world: A review. Talanta 2002, 58, 201-235. [CrossRef]

6. Siddique, A.E.; Rahman, M.; Hossain, M.I.; Karim, Y.; Hasibuzzaman, M.M.; Biswas, S.; Islam, M.S.; Rahman, A.; Hossen, F.; Mondal, V.; et al. Association between chronic arsenic exposure and the characteristic features of asthma. Chemosphere 2020, 246, 129750. [CrossRef]

7. Paul, S.K.; Islam, M.S.; Hasibuzzaman, M.M.; Hossain, F.; Anjum, A.; Saud, Z.A.; Haque, M.M.; Sultana, P.; Haque, A.; Andric, K.B.; et al. Higher risk of hyperglycemia with greater susceptibility in females in chronic arsenic-exposed individuals in Bangladesh. Sci. Total Environ. 2019, 668, 1004-1012. [CrossRef]

8. IARC Monographs on the Identification of Carcinogenic Hazards to Human. Available online: https: //monographs.iarc.fr/agents-classified-by-the-iarc/ (accessed on 31 May 2020).

9. Arsenic in Drinking Water. Available online: https://www.who.int/water_sanitation_health/water-quality/ guidelines/arsenic-information/en/ (accessed on 31 May 2020).

10. Vaishya, R.C.; Gupta, S.K. Modeling arsenic(III) adsorption from water by sulfate-modified iron oxide-coated sand (SMIOCS). J. Chem. Technol. Biotechnol. 2002, 89, 73-80. [CrossRef]

11. Martinson, C.A.; Reddy, K.J. Adsorption of arsenic(III) and arsenic(V) by cupric oxide nanoparticles. J. Colloid Interf. Sci. 2009, 336, 406-411. [CrossRef]

12. Mandal, S.; Padhi, T.; Patel, R.K. Studies on the removal of arsenic(III) from water by a novel hybrid material. J. Hazard. Mater. 2011, 192, 899-908. [CrossRef]

13. Ren, Z.; Zhang, G.; Paul Chen, J. Adsorptive removal of arsenic from water by an iron-zirconium binary oxide adsorbent. J. Colloid Interf. Sci. 2011, 358, 230-237. [CrossRef]

14. Ferguson, J.F.; Gavis, J. A review of arsenic cycle in natural waters. Water Res. 1972, 6, 1259-1274. [CrossRef]

15. Wu, K.; Liu, T.; Xue, W.; Wang, X. Arsenic(III) oxidation/adsorption behaviors on a new bimetal adsorbent of Mn-oxide-doped Al oxide. Chem. Eng. J. 2012, 192, 343-349. [CrossRef]

16. Ogata, F.; Nakamura, T.; Toda, M.; Otani, M.; Kawasaki, N. Evaluation of nickel-aluminum complex hydroxide for adsorption of chromium(VI) ion. Chem. Pharm. Bull. 2020, 68, 70-76. [CrossRef]

17. Ogata, F.; Ueta, E.; Kawasaki, N. Characteristics of a novel adsorbent Fe-Mg-type hydrotalcite and its adsorption capability of $\mathrm{As}(\mathrm{III})$ and $\mathrm{Cr}(\mathrm{VI})$ from aqueous solution. J. Ind. Eng. Chem. 2018, 59, 56-63. [CrossRef]

18. Zhang, X.; Guo, L.; Huang, H.; Jiang, Y.; Li, M.; Leng, Y. Removal of phosphorus by the core-shell bio-ceramic/Zn-layered double hydroxides (LDHs) composites for municipal wastewater treatment in constructed rapid infiltration system. Water Res. 2016, 96, 280-291. [CrossRef]

19. Radha, A.V.; Kamath, P.V. Aging of trivalent metal hydroxide/oxide gels in divalent metal salt solutions: Mechanism of formation of layered double hydroxides (LDHs). Bull. Mater. Sci. 2003, 26, 661-666. [CrossRef]

20. Ogata, F.; Nagai, N.; Toda, M.; Otani, M.; Nakamura, T.; Kawasaki, N. Evaluation of the interaction between borate ions and nickel-aluminum complex hydroxide for purification of wastewater. Chem. Pharm. Bull. 2019, 67, 487-492. [CrossRef] 
21. Wu, P.; Xia, L.; Liu, Y.; Wu, J.; Chen, Q.; Song, S. Simultaneous sorption of arsenate and fluoride on calcined Mg-Fe-La hydrotalcite-like compound from water. ACS Sustain. Chem. Eng. 2018, 6, 16287-16297. [CrossRef]

22. Chitrakar, R.; Tezuka, S.; Sonoda, A.; Sakane, K.; Ooi, K.; Hirotsu, T. Synthesis and phosphate uptake behavior of Zr4+ incorporated MgAl-layered double hydroxides. J. Colloid Interf. Sci. 2007, 313, 53-63. [CrossRef]

23. Miyauchi, H.; Yamamoto, T.; Chitrakar, R.; Makita, Y.; Wang, Z.; Kawai, J.; Hirotsu, T. Phosphate adsorption site on zirconium ion modified MgAl-layered double hydroxides. Top Catal. 2009, 52, 714-723. [CrossRef]

24. Ogata, F.; Iijima, S.; Toda, M.; Otani, M.; Nakamura, T.; Kawasaki, N. Characterization and phosphate adsorption capability of novel nickel-aluminum-zirconium complex hydroxide. Chem. Pharm. Bull. 2020, 68, 292-297. [CrossRef]

25. Ymashita, T.; Ozawa, Y.; Nakajima, N.; Murata, T. Collection of uranium from sea water with hydrous oxide adsorbents. 1. Ion exchange properties and uranium adsorption of hydrous titanium(IV) oxide. Nippon Kagaku Kaishi 1978, 8, 1057-1061. [CrossRef]

26. Ogata, F.; Ueta, E.; Toda, M.; Otani, M.; Kawasaki, N. Adsorption of phosphate ions from an aqueous solution by calcined nickel-cobalt binary hydroxide. Water Sci. Technol. 2017, 75, 94-105. [CrossRef]

27. Türk, T.; Alp, İ. Arsenic removal from aqueous solutions with Fe-hydrotalcite supported magnetite nanoparticle. J. Ind. Eng. Chem. 2014, 20, 732-738. [CrossRef]

28. Lagergren, S. Zur theorie der sogenannten adsorption geloster stoffie, Kunglia Svenska Vetenskapsakademiens. Handlingar 1898, 24, 1-39.

29. Ho, Y.S.; McKay, G. Pseudo-second order model for sorption process. Pro Biochem. 1999, 34, 451-465. [CrossRef]

30. Raven, K.P.; Jain, A.; Loeppert, R.H. Arsenite and arsenate adsorption on ferrihydrite: Kinetics, equilibrium, and adsorption evelopes. Environ. Sci. Technol. 1998, 32, 344-349. [CrossRef]

31. Simonin, J.P. On the comparison of pseudo-first order and pseudo-second order rate laws in the modeling of adsorption kinetics. Chem. Eng. J. 2016, 300, 254-263. [CrossRef]

32. Ho, Y.S. Selection of optimum sorption isotherm. Carbon 2004, 42, 2115-2116. [CrossRef]

33. Wu, K.; Liu, R.; Li, T.; Liu, H.; Peng, J.; Qu, J. Removal of arsenic(III) from aqueous solution using a low-cost by-product in Fe-removal plants-Fe-based backwashing sludge. Chem. Eng. J. 2013, 226, 292-401. [CrossRef]

34. Langmuir, I. The constitution and fundamental properties of solids and liquids. J. Am. Chem. Soc. 1916, 38, 2221-2295. [CrossRef]

35. Freundlich, H.M.T. Over the adsorption in solution. J. Phys. Chem. 1906, 57, 385-471.

36. Li, H.T.; Xu, M.C.; Shi, Q.; He, B.L. Isotherm analysis of phenol adsorption on polymeric adsorbents from nanoaqueous solution. J. Colloid. Interf. Sci. 2004, 271, 47-54. [CrossRef]

37. Abe, I.; Hayashi, K.; Kitagawa, M. Studies on the adsorption of surfactants on activated carbons. I. Adsorption of nonionic surfactants. Yukagaku 1976, 25, 145-150.

38. Tiwari, D.; Lee, S.M. Novel hybrid materials in the remediation of ground waters contaminated with As(III) and As(V). Chem. Eng. J. 2012, 204-206, 23-31. [CrossRef]

39. Hlavay, J.; Polyak, K. Determination of surface properties of iron hydroxide-coated alumina adsorbent prepared for removal of arsenic from drinking water. J. Colloid Interf. Sci. 2005, 284, 71-77. [CrossRef]

40. Yoshida, I.; Kobayashi, H.; Ueno, K. Selective adsorption of arsenic ions on silica gel impregnated with ferric hydroxide. Anal. Lett. 1976, 9, 1125-1133. [CrossRef]

41. Makris, K.C.; Sarkar, D.; Datta, R. Evaluating a drinking-water waste by-product as a novel sorbent for arsenic. Chemosphere 2006, 64, 730-741. [CrossRef]

(C) 2020 by the authors. Licensee MDPI, Basel, Switzerland. This article is an open access article distributed under the terms and conditions of the Creative Commons Attribution (CC BY) license (http://creativecommons.org/licenses/by/4.0/). 